\title{
Combined DNA extraction and antibody elution from filter papers for the assessment of malaria transmission intensity in epidemiological studies
}

\author{
Amrish Baidjoe ${ }^{1 \dagger}$, Will Stone ${ }^{1 \dagger}$, Ivo Ploemen ${ }^{1}$, Shehu Shagari ${ }^{2}$, Lynn Grignard ${ }^{4}$, Victor Osoti ${ }^{2}$, Euniah Makori ${ }^{2}$, \\ Jennifer Stevenson ${ }^{3}$, Simon Kariuki ${ }^{2}$, Colin Sutherland ${ }^{4}$, Robert Sauerwein ${ }^{1}$, Jonathan Cox ${ }^{3}$, Chris Drakeley ${ }^{4}$ \\ and Teun Bousema ${ }^{1,4^{*}}$
}

\begin{abstract}
Background: Informing and evaluating malaria control efforts relies on knowledge of local transmission dynamics. Serological and molecular tools have demonstrated great sensitivity to quantify transmission intensity in low endemic settings where the sensitivity of traditional methods is limited. Filter paper blood spots are commonly used a source of both DNA and antibodies. To enhance the operational practicability of malaria surveys, a method is presented for combined DNA extraction and antibody elution.

Methods: Filter paper blood spots were collected as part of a large cross-sectional survey in the Kenyan highlands. DNA was extracted using a saponin/chelex method. The eluate of the first wash during the DNA extraction process was used for antibody detection and compared with previously validated antibody elution procedures. Antibody elution efficiency was assessed by total IgG ELISA for malaria antigens apical membrane antigen-1 (AMA-1) and merozoite-surface protein-1 (MSP-1 ${ }_{42}$ ). The sensitivity of nested $18 \mathrm{~S}$ rRNA and cytochrome $b$ PCR assays and the impact of doubling filter paper material for PCR sensitivity were determined. The distribution of cell material and antibodies throughout filter paper blood spots were examined using luminescent and fluorescent reporter assays.

Results: Antibody levels measured after the combined antibody/DNA extraction technique were strongly correlated to those measured after standard antibody elution $(p<0.0001)$. Antibody levels for both AMA-1 and MSP-1 ${ }_{42}$ were generally slightly lower (11.3-21.4\%) but age-seroprevalence patterns were indistinguishable. The proportion of parasite positive samples ranged from $12.9 \%$ to $19.2 \%$ in the different PCR assays. Despite strong agreement between outcomes of different PCR assays, none of the assays detected all parasite-positive individuals. For all assays doubling filter paper material for DNA extraction increased sensitivity. The concentration of cell and antibody material was not homogenously distributed throughout blood spots.

Conclusion: Combined DNA extraction and antibody elution is an operationally attractive approach for high throughput assessment of cumulative malaria exposure and current infection prevalence in endemic settings. Estimates of antibody prevalence are unaffected by the combined extraction and elution procedure. The choice of target gene and the amount and source of filter paper material for DNA extraction can have a marked impact on PCR sensitivity.
\end{abstract}

Keywords: Plasmodium, Malaria, Antibodies, IgG, DNA, Submicroscopic, Extraction, Transmission, PCR, ELISA

\footnotetext{
* Correspondence: teun.bousema@lshtm.ac.uk

${ }^{\dagger}$ Equal contributors

'Department of Medical Microbiology, Radboud University Nijmegen Medical Centre, Nijmegen, the Netherlands

${ }^{4}$ Department of Immunology \& Infection, Faculty of Infectious and Tropical Diseases, London School of Hygiene and Tropical Medicine, London WC1E $7 \mathrm{HT}, \mathrm{UK}$

Full list of author information is available at the end of the article
}

\section{Biomed Central}

(c) 2013 Baidjoe et al.; licensee BioMed Central Ltd. This is an Open Access article distributed under the terms of the Creative Commons Attribution License (http://creativecommons.org/licenses/by/2.0), which permits unrestricted use, distribution, and reproduction in any medium, provided the original work is properly cited. 


\section{Background}

To effectively implement and evaluate malaria control efforts a detailed knowledge is required of Plasmodium carriage and transmission within target populations. Transmission intensity is traditionally assessed using mosquito trapping techniques to determine exposure to infected Anopheles mosquitoes. In low endemic areas, where vector populations may be sparsely infected, small or heterogeneously distributed, trapping becomes operationally and technically unattractive [1-3]. A frequently used alternative is the prevalence of malaria infection in human populations, which is typically assessed by light microscopy. However, the limited detection limit and operational constraints of microscopical surveillance present a major barrier to its application in low endemic areas [4-8]. With patterns of reducing malaria transmission intensity in many African settings [9-14], it will become increasingly important to have sensitive alternatives for population level surveillance in areas approaching a phase of elimination $[7,15]$.

Serological and molecular tools have been proposed to be particularly useful for monitoring transmission intensity and determining parasitaemia among populations in areas of low endemicity. Antibody responses to recombinant asexual malaria antigens are strongly associated with entomological measures of transmission intensity and microscopical parasite prevalence [16], but at low endemicity have a greater discriminative power [3]. Low level transmission may be detectable in the absence of microscopically detectable infection [17] and serological markers can detect spatial variation in transmission intensity [18] and the efficacy of interventions [19]. While serology can be used to detect spatial and temporal patterns in transmission intensity [20], antibody responses are long-lived and, unless sampling is restricted to very young age groups, additional tools are required to quantify on-going transmission. The polymerase chain reaction (PCR) is a highly sensitive method for detecting Plasmodium infection at all levels of endemicity [21-23]. In a meta-analysis comprising 106 surveys, microscopy detected $54.1 \%$ of all PCR-detected infections; a figure that decreased to below 20\% in low endemic settings [24]. Sub-microscopic parasite carriage has been shown to contribute significantly to the malaria infectious reservoir $[25,26]$ and is therefore of relevance for inclusion in control programmes. Actively identifying infected individuals using PCR may, therefore, be critically important when attempting to interrupt malaria transmission $[7,27,28]$. While PCR is commonly used as gold standard for detecting all parasitaemic individuals, there is variation between different PCR approaches [29,30] and DNA extraction from filter papers may vary in efficiency [30,31].

In the context of malaria elimination, there is a need to optimize molecular and serological assays for rapid and simultaneous assessment of the significant numbers of samples that will be generated by large scale, long term surveillance [32]. At present, DNA extraction and antibody elution are the most time consuming and laborious aspects of serological and molecular assessments. It would be operationally attractive to source DNA and antibodies from the same blood spots, as this would allow serology and PCR to be conducted in unison, increasing throughput while decreasing costs.

Here, a simple method for concurrently extracting antibodies and DNA from filter paper blood spots is presented. Antibody responses to malaria antigens are assessed to compare the efficacy of antibody elution. PCR assays using two different target genes are compared, and two sources of variation in PCR outcome are explored: the distribution of parasite material on filter papers and the amount of filter paper material that is used for DNA extraction.

\section{Methods}

\section{Study area and subjects}

Blood spot samples were collected in 2011 as part of a cross-sectional study in the Western Kenyan Highlands (latitude $-0.470431^{\circ}$, longitude $34.842628^{\circ}$ ), an area of seasonal malaria transmission in which $P$. falciparum dominates. The objectives of the original study and details of the study area are detailed elsewhere [33]. Ethical approval was granted by the Scientific Steering Committee (SSC), the Ethical Review Committee (ERC) of the Kenya Medical Research Institute (KEMRI) Nairobi (proposal numbers SSC 2163, 2181 and 1589), the London School of Hygiene \& Tropical Medicine ethics committee (\#6111), and from Centers for Disease Control and Prevention (with exempt status) [33]. Blood derived from a finger prick was blotted onto Whatman no. 3 filter paper (Whatman, Maidstone, UK) and was dried overnight before storage with silica gel at $-20^{\circ} \mathrm{C}$. Each filter paper contained three individual blood spots of indeterminate volume. Filter papers were wetted through by blood spots completely, as described by Corran et al. [34]. A subset of 240 randomly selected blood spots was selected for both PCR and enzyme-linked immunosorbent assay (ELISA).

\section{Standard antibody elution}

The full protocol of the elution and extraction steps is provided in the supporting documentation (Additional file 1). Three filter paper discs of $2.5 \mathrm{~mm}$ in diameter were punched from the centre of each dried blood spot. Filter paper discs were immediately placed into the wells of replicate $2.0 \mathrm{ml} 96$ deep well plates (Axygen Biosciences, CA, USA), one containing individual discs, the other pairs of discs. Each plate contained 80 samples so that the sample number in each corresponded to that of 
2 ELISA plates, leaving wells free for controls. For standard elution single filter papers were incubated in $1120 \mu \mathrm{l}$ of a $0.5 \%$ sodium azide/PBS solution [34]. Plates were sealed and placed onto a plate shaker on their side, allowing the cut filter paper discs to move freely along the length of their wells. After overnight incubation, the eluate was stored at $-80^{\circ} \mathrm{C}$. The final serum dilution of the eluate based on estimates of the volume of whole blood in a $2.5 \mathrm{~mm}$ filter paper disc was 1:400 [34].

\section{Combined antibody elution and DNA extraction}

Filter paper discs were prepared and stored in deep well plates as for standard antibody elution. For combined DNA extraction and antibody elution (henceforth combined elution), $1120 \mu \mathrm{l}$ of a $0.5 \%$ saponin/PBS solution was added to each well and plates were incubated overnight as for standard elution. $200 \mu \mathrm{l}$ of the eluate, which contained all soluble elements including antibodies, was transferred to a new plate and stored at $-80^{\circ} \mathrm{C}$ until use in ELISA. To continue with DNA extraction, the remaining saponin solution was aspirated and $1 \mathrm{ml}$ of PBS washing solution was added to each well at $4^{\circ} \mathrm{C}$. Plates were horizontally incubated on a shaker for one hour as above, before PBS was aspirated and discarded. $150 \mu \mathrm{l}$ of a $6 \%$ Chelex in DNase/ RNase free water solution was added to each sample. Plates were sealed using adhesive foil mats (Axygen Biosciences, CA, USA) and incubated in a water bath for $3 * 10$ minutes at $97^{\circ} \mathrm{C}$. Between 10 minute incubations plates were briefly centrifuged in order to relieve pressure and ensure optimal DNA elution. After the last incubation plates were spun down at maximum speed for 5 minutes to allow the Chelex to settle. $120 \mu \mathrm{l}$ of the DNA containing solution was taken and aliquoted into new plates. Samples were stored at $-80^{\circ} \mathrm{C}$ until further analyses. To exclude the risk of cross-contamination during extraction materials were extensively tested using positive and negative controls (2.5\% Plasmodium DNA and blank wells respectively). No cross-contamination was observed during extraction.

\section{AMA-1 and MSP-1 ${ }_{42}$ ELISA}

IgG antibody responses against AMA-1 (BPRC, $0.3 \mu \mathrm{g} /$ $\mathrm{ml}$ coating concentration) and MSP- $1_{42}$ (FVO, $0.2 \mu \mathrm{g} / \mathrm{ml}$ coating concentration) were detected as previously described [16,35]. Test sera were analysed in duplicate at 1:1,000 (MSP-1 42 ) or 1:2,000 (AMA-1) in PBST/Marvel milk powder (Cadbury, UK). Blank wells and a serial dilution of pooled hyper-immune sera were included in duplicate on each plate to correct for non-specific antibody reactivity and standardise responses for inter-plate variation. Seroprevalence of IgG antibodies to both antigens was determined using a mixture model as described previously [16,34]. The model was used on each population of samples, giving four separate positivity thresholds (one each for AMA-1 standard elution, AMA-1 combined elution, MSP-1 42 standard elution, and $\mathrm{MSP}-1_{42}$ combined elution).

\section{Parasite detection by PCR}

Three nested PCR assays were evaluated; an 18S PCR targeting the small ribosomal subunit of Plasmodium falciparum developed by Snounou et al. [22] and two variations of a more recent assay which targets the mitochondrial cytochrome b as described by Steenkeste et al. [30,36]. Because of inconsistent amplification of amplicons generated by the nest 1 (N1) primers described by Steenkeste et al. primers of the N1 reaction were redesigned. The $18 \mathrm{~S}$ PCR was performed according to the original protocol except that the quantity of template used in the N1 reaction was increased from $1 \mu \mathrm{l}$ to $5 \mu \mathrm{l}$. In every set of PCR conditions $5 \mu \mathrm{L}$ template was used in the $\mathrm{N} 1$ reaction and $1.5 \mu \mathrm{l}$ of product in the N2 reaction. For a more detailed overview of primer sequences, product sized and PCR cycling conditions see Additional file 1. Pooled DNA extracts from P. falciparum NF54 cultured in Nijmegen, the Netherlands were run on every PCR plate as a positive control, alongside a negative water control. Positive control was diluted to the extent that both $\mathrm{N} 1$ and N2 fragments were sufficiently amplified so that both amplicons could be visualized on gel. N1 and N2 products were mixed and $10 \mu \mathrm{l}$ was visualized on a $0.8 \%$ agarose gel by electrophoresis in $0.5 \mathrm{x}$ Tris-acetate-EDTA buffer (0.04 M Tris-acetate and $1 \mathrm{mM}$ EDTA, $\mathrm{pH}$ 8.0). Each assay was assessed using single and double filter papers, creating a total of 6 PCR conditions for comparison.

\section{Distribution of parasite material on filter papers}

To visualize cell material in filter paper blood spots two C57BL/6 mice were infected as previously described with a transgenic Plasmodium berghei strain (PbGFPLuc $_{\text {con }}$ ) expressing a fusion protein of GFP and Luciferase from the eef1a promoter $[37,38]$. The original studies that were used as a source of blood material were performed according to the regulations of the Dutch "Animal On Experimentation act" and the European guidelines 86/609/EEG; approval was obtained from the Radboud University Experimental Animal Ethical Committee (RUDEC 2009-019). $100 \mu \mathrm{l}$ of blood from the infected mice was collected in heparinised tubes and mixed with $3.2 \mu \mathrm{l}$ of highly concentrated $(67 \mathrm{mg} / \mathrm{ml})$ D-luciferin (Xenogen, CA, USA) dissolved in PBS [37]. $30 \mu \mathrm{l}$ of this mixture was pipetted onto Whatman no. 3 paper (Whatman, Maidstone, UK) in a manner closely approximating that of blood spot collection in the field. Drops were first formed on the pipette tip before contact with the paper was made, and filter papers were wetted 
through completely. Blood spots were left to dry for 15 minutes before luminescent imaging was performed using a Lumina Caliper (PerkinElmer, MA, USA) $(5 \mathrm{~cm}$ FOV, medium binning factor, 1 second exposure). This process was repeated for two blood spots. A blood spot without the addition of D-luciferin was used as a negative control.

\section{Distribution of antibody material on filter papers}

Batches of $100 \mu \mathrm{l}$ whole human blood were mixed with fluorescent labeled anti- APC-Cy7-anti-CD4 (Biolegend, CA, USA) and/or anti-human APC-IL-2. (eBioscience, CA, USA). Blood spot preparation and imaging was performed as in the cell distribution experiments.

\section{Data analysis}

Statistical analysis was conducted using STATA 12 (StataCorp., TX, USA) and GraphPad Prism 5.0 (GraphPad Software Inc., CA, USA). IgG responses between groups of paired data were compared by Wilcoxon signed rank test. Seroprevalence comparisons were made using Chi-square test, with a test for trend in proportions. Associations between IgG responses expressed as antibody titre were quantified by Spearman correlation coefficients, and differences between elution approaches tested by linear regression presenting 95\% confidence intervals $(\mathrm{CI})$. The level of agreement, kappa value and sensitivity were assessed by comparing individual PCR conditions with 'true positivity' that was defined as positivity in any one of the PCR assay variants. The difference in the proportion of positive samples between PCR conditions was tested by McNemar's chisquare for paired data. To minimize the influence of possible false positive PCR results on sensitivity estimates, calculations were repeated after 'true positivity' was defined as a positive PCR in at least two of the PCR conditions. For the cell/antibody distribution experiments Living image 3.2 was used (PerkinElmer, MA, USA). To map the relative fluorescence/intensity in different areas of the blood spot they were overlaid with grids containing cells of $2.5 \mathrm{~mm}^{2}$. Grids extended to the spots edges, and cells were excluded from analysis if their area was not entirely filled with dried blood. For comparison between cells, fluorescence and luminescence values were calculated as a proportion of the highest cell value.

\section{Results}

\section{Antibody responses}

Antibodies were eluted from 236 filter papers by both the standard elution procedure and the combined elution procedure. For both AMA- 1 and MSP- $1_{42}$, a strong positive correlation was observed between the IgG responses of filter paper blood samples eluted by standard and combined methods (Figure 1). While strongly correlated, there was a tendency toward higher antibody responses when samples were eluted using the standard methodology for both antigens $(\mathrm{p}=<0.0001)$. For antibody level (optical density), responses were on average $11.3 \%$ higher for AMA-1, and 21.4\% higher for MSP-1 $1_{42}$ when using standard rather than combined elution. Linear regression analysis showed that for AMA-1 an increase of titre 1 using combined elution was associated with an increase of titre 1.773 (95\% CI 1.712-1.834; p < 0.0001) using standard elution. For MSP- $1_{42}$ an increase of titre 1 using combined elution was associated with an increase of titre 1.811 (95\% CI 1.647-1.975, $\mathrm{p}<0.0001)$ using standard elution. For use as marker of exposure, antibody responses against AMA-1 and MSP- $1_{42}$ are commonly combined to give a prevalence of any anti-P. falciparum antibodies $[17,18,20]$. Between standard and combined elution methods seroprevalence of antibody responses to AMA-1 and $\mathrm{MSP}-1_{42}$ did not differ significantly $(\mathrm{p}>0.8)$, and for both methods showed a strong age-dependent increase (Figure 2; $\mathrm{p}<0.0001)$. Within age-groups, antibody seroprevalence did not differ significantly between elution methods ( $\mathrm{p}>0.5$ ).

\section{Parasite prevalence by PCR}

Parasite prevalence by PCR differed between different methodologies and ranged from 12.9\% (31/240) when the $18 \mathrm{~s}$ rRNA-based PCR was used with single filter paper discs to $19.2 \%(46 / 240)$ when the original cytochrome b based PCR was used with two filter paper discs (Table 1). The level of agreement between these two estimates, representing the two extremes of parasite prevalence, was high (90.4\%, kappa 0.65$)$ but the cytochrome b PCR with two filter paper discs resulted in significantly more positive results compared to the $18 \mathrm{~s}$ rRNA based PCR with single filter paper discs $(\mathrm{p}=0.002)$. When true positivity was defined as a sample being positive in any one of the assays, the standard cytochrome $b$ assay using DNA from two filter paper discs showed the highest sensitivity (83.6\% C.I. 71.2-92.2\%). Defining true positivity as a positive signal in at least two of the PCR assays did not change the estimates of sensitivity and kappa considerably (see Additional file 2).

Doubling filter paper material for DNA extraction increased the sensitivity of PCR assays by $5.4-16.3 \%$. When pairs of results from the same PCR assay but using DNA template from single or double filters were compared ( $n=720$ pairs), the latter resulted in significantly more parasite positive results $(\mathrm{p}=0.013) .130$ of the PCRs performed on DNA from double filter paper punches were PCR positive, compared to 111 of the PCRs performed on DNA from single filter paper punches. Surprisingly, 18.0\% (20/111) of the samples that were positive in a PCR using template from a single filter punch were negative in the 

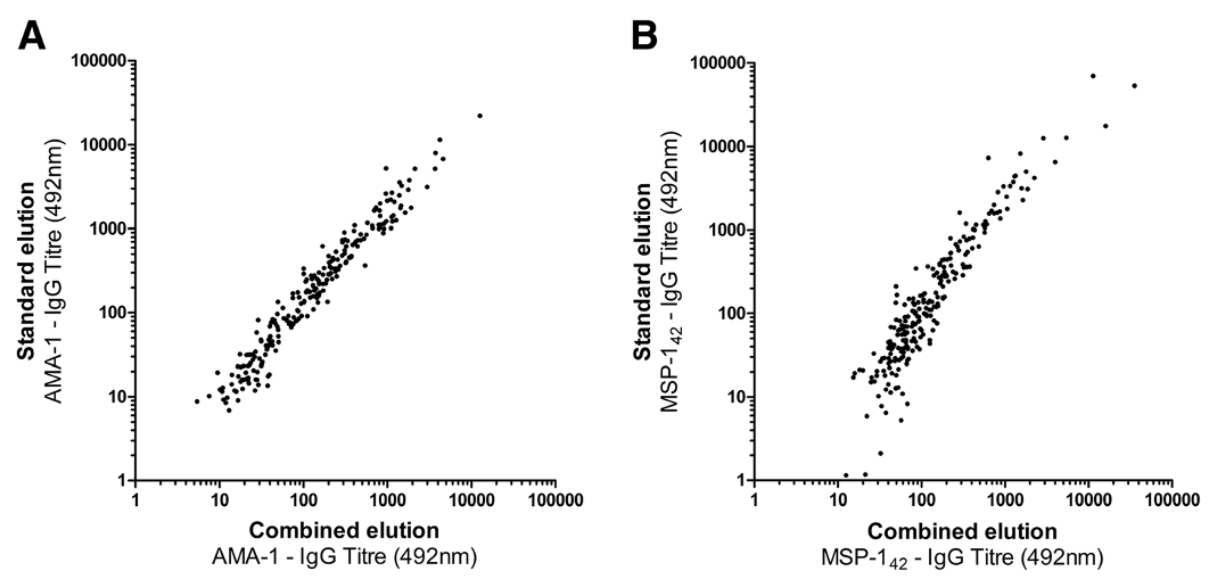

Figure 1 Antibody level from standard and dual filter paper blood spot elution methods for AMA-1 and MSP-1 ${ }_{42}$. A. Scatter plot showing anti-AMA-1 lgG level detected in 236 individuals by standard ( $x$-axis) and combined ( $y$-axis) elution of filter paper blood spots. $R^{2}$ (linear regression) $=0.93(p=<0.0001)$. B. Scatter plot showing anti-MSP-1 42 lgG level detected in 236 individuals using standard ( $x$-axis) and combined (y-axis) elution of filter paper blood spots. $R^{2}$ (linear regression) $0.671(p=<0.0001)$.

PCR performed when two punches were taken from the same filter paper.

Doubling filter paper material also appeared to increase the consistency of PCR outcomes on the same DNA material, albeit not statistically significant. When the $18 \mathrm{~s}$ rRNA-based PCR and both cytochrome b based PCRs were performed on material from the same extraction, inconsistent results (i.e. one or two but not all three PCR assays giving amplification) were observed for $8.3 \%(20 / 240)$ of the samples when material from single filter paper punches was used compared to $5.9 \%$ (14/ $240)$ of samples when filter paper material was doubled (Table 2, $\mathrm{p}=0.36$ ).

\section{Distribution of parasite material on blood spots}

Luminescence produced by GFP expression in $\mathrm{Pb}$ GFPluc $_{\text {con }}$ infected blood samples was previously shown

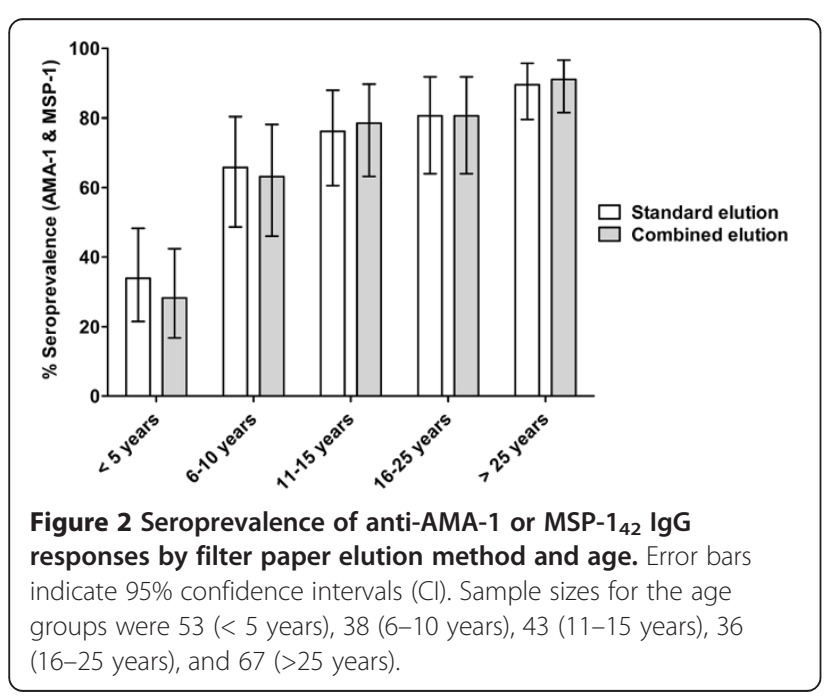

to correlate strongly with parasitaemia [39]. Here, the distribution of DNA on filter paper was assessed by measuring the luminescent intensity in dried blood spots from mice infected with $\mathrm{Pb}$-GFPluc con $_{\text {[38]. Cell by cell }}$ luminescence analysis of the grid overlaying the blood spot was used to describe heterogeneity in parasite material in different parts of the blood spot. Both blood spots tested showed a considerable degree of heterogeneity in the distribution of parasite material (Figure 3). In the two separate experiments, $25 \%$ and $64 \%$ of the grid cells contained less than $85 \%$ of the parasite material of the grid cell with the highest quantity. Parasite material seemed less concentrated towards the extreme edges of the blood spot; the grid cell with the lowest parasite quantity contained $70 \%$ of the maximum value (Figure 3).

\section{Distribution of antibody material on blood spots}

The distribution of antibodies on filter paper was evaluated by the adding two marker molecules which have approximately the same molecular weight of human IgG and have no detectable interaction with other components in human blood. Analysis of fluorescence intensity based on the overlaying grid showed that also antibodies were heterogeneously distributed throughout the blood spot (Figure 3). In the two separate experiments, $65 \%$ of the grid cells contained less than $85 \%$ of the parasite material of the grid cell with the highest quantity. Contrary to the observations on parasite material, there was no evident pattern in antibody concentration on the blood spot and concentrations of antibodies did not appear to be higher in the middle of the spot (Figure 3). The grid cell with the lowest antibody concentration contained $67 \%$ of the maximum value. 
Table 1 Agreement between $18 \mathrm{~s}$, modified cytochrome $b$ and original cytochrome PCR assays

\begin{tabular}{llllll}
\hline PCR assay & Filter paper number & Positivity, \% (n/N) & Agreement, \% & Kappa & Sensitivity, \% (95\% Cl) \\
\hline 18S rRNA & Single & $12.9(31 / 240)$ & 90.0 & 0.666 & $56.4(42.3-69.7)$ \\
& Double & $16.7(40 / 240)$ & 93.8 & 0.804 & $72.7(59.0-83.9)$ \\
Modified Cytochrome B & Single & $15.4(37 / 240)$ & 92.5 & 0.760 & $67.3(53.3-79.3)$ \\
& Double & $18.3(44 / 240)$ & 95.4 & 0.861 & $80.0(67.0-89.6)$ \\
Original Cytochrome B & Single & $17.9(43 / 240)$ & 95.0 & 0.847 & $78.2(65.0-88.2)$ \\
& Double & $19.2(46 / 240)$ & 96.3 & 0.887 & $83.6(71.2-92.2)$ \\
\hline
\end{tabular}

The agreement, kappa value and sensitivity were calculated by comparing individual PCR conditions with 'true positivity' that was defined as positivity in any one of the PCR assay variants. The abbreviation $n / N$ indicates PCR positive individuals $(n)$ as a proportion of the total sample size (N).

\section{Discussion}

The methodology described in this report offers a costefficient high-throughput approach to preparing large numbers of filter paper samples for the assessment of cumulative malaria exposure and current infection status. Used in concert, serological and molecular assays can provide detailed insight into the transmission dynamics of Plasmodium.

The utility of serological assessments in malaria surveillance has been evidenced by numerous studies of the antibody responses of endemic populations to recombinant Plasmodium [40] and Anopheles [41-43] antigens. Recently the importance of molecular tools in malaria surveillance has been emphasised, as it has become apparent that the extent and relevance of sub-microscopic malaria infections in low endemic areas may be much greater than previously assumed [6,24]. As the number of areas making efforts to reduce or interrupt native malaria transmission grows so will the importance of sensitively detecting malaria exposure $[7,32,44]$. As such, the development of strategies to ease sample collection and processing during wide-scale population level surveillance is both timely and apposite to the wider malaria eradication agenda. The use of filter papers for blood collection and their subsequent storage and processing for sero-epidemiological analyses was discussed in depth by Corran et al. [34]. Since this time many studies have benefitted from the use of filter paper blood spots as a source of serum antibodies to reveal agedependent [20], spatial [17-19] and temporal [45] patterns in cumulative malaria exposure. In the current study antibody levels (OD) from the standard elution methodology and the combined elution methodology (in which a portion of the filter paper eluate undergoes onward processing for DNA extraction) show a strong and highly significant correlation. Though the relationship between absolute antibody titre in paired measures was strongly related, higher antibody levels were generally observed when blood spots underwent standard elution procedures. The reason for this is unknown and may reflect differences in the relative concentration of detergent. The lower antibody yield in the combined method warns against using the two approaches simultaneously; quantitative outcomes of individual samples cannot be directly compared when different elution methods have been used. In epidemiological studies it is more common to analyse variation in malaria exposure using measures of (age-dependent) antibody seroprevalence $[19,20,46]$. In the current study, seroprevalence did not differ significantly between the two elution methods, and both methods showed the same age-dependent acquisition of antibody responses. This indicates that combining antibody elution with DNA extraction is an operationally attractive alternative to the standard method of antibody elution that can reliably be used to compare antibody responses between populations of blood donors.

The elution of antibodies during the process of DNA extraction adds an advantage to the chelex/saponin extraction method, which is probably the most widely used extraction method in epidemiological malaria studies. This extraction method has repeatedly been shown to give comparable results when compared to commercial extraction kits $[47,48]$; although in case of older or incorrectly dried and stored filter papers commercial kits may be recommended [31]. Because of its evident superior sensitivity compared to microscopy [6,24], PCR may be considered to be the gold standard for the detection of malaria infections in epidemiological studies. The current study highlights three relevant caveats to this assumption. Firstly, different PCRs differ in their

Table 2 Consistency of outcomes in different PCR assays in relation to the amount of filter paper material used for extraction

\begin{tabular}{lllll}
\hline Filter paper number & Never positive (\%) & Positive in 1/3 PCR assays (\%) & Positive in 2/3 PCR assays (\%) & Positive in 3/3 PCR assays (\%) \\
\hline Single & $80.8(194 / 240)$ & $2.9(7 / 240)$ & $5.4(13 / 240)$ & $10.8(26 / 240)$ \\
Double & $79.6(191 / 240)$ & $1.3(3 / 240)$ & $4.6(11 / 240)$ & $14.6(35 / 240)$ \\
\hline
\end{tabular}

The proportion $(\mathrm{n} / \mathrm{N})$ of positive PCR assays when aliquots of the same extracted material was used in three different PCR assays. 


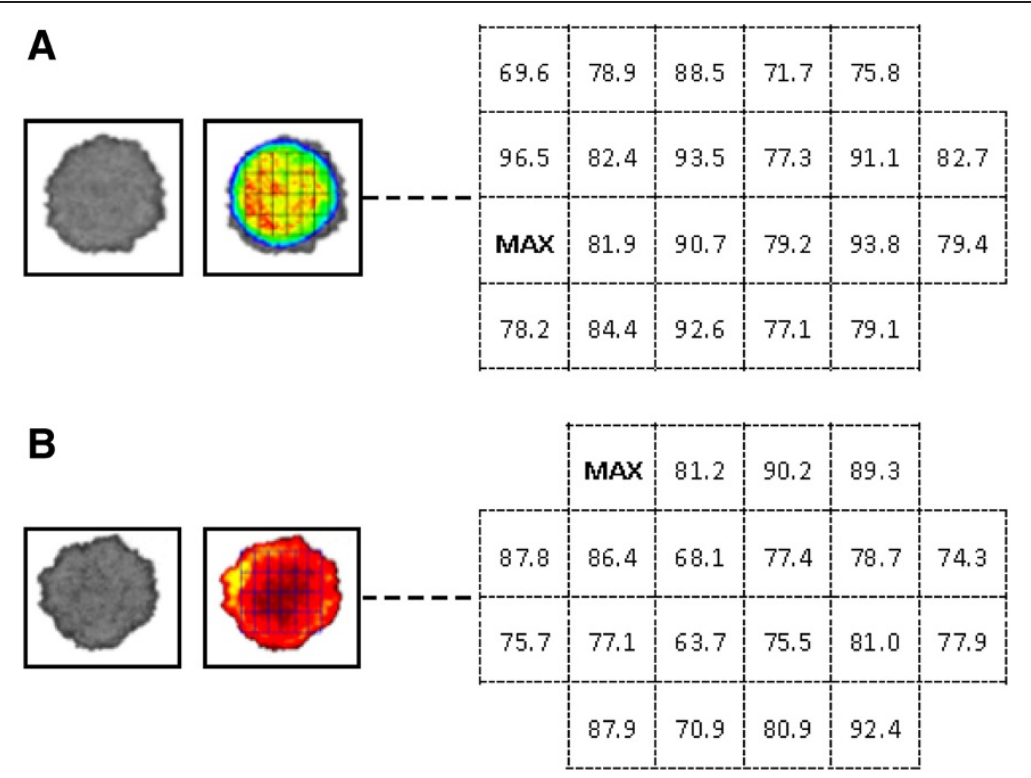

Figure 3 DNA/Cell and antibody distribution on filter paper. A. Photograph of one of the two blood spots analysed for cell material distribution, in which luminescence intensity is proportional to the density of cell material. Luminescence intensity values in the cells of the overlying grid are calculated as a proportion of the highest cell value, and are presented in the adjacent grid schema. B. Photograph of one of the two blood spots analysed for antibody material distribution, in which fluorescence intensity is proportional to the density of antibodies. Fluorescence intensity values are calculated and presented as in Figure 3A.

sensitivity to detect malaria parasite. Although a recent meta-analysis found no differences in sensitivity compared to microscopy for different nested PCR assays [24], the current study presents evidence for a higher sensitivity of PCR based on the cytochrome b target gene compared to the most widely used $18 \mathrm{~s}$ rRNA target gene $[31,49]$. This may be due to better conservation of mitochondrial material [29]. The current study shows no advantage of the newly designed primers for the cytochrome $b$ gene in overcoming the anecdotal problems of inconsistency of PCR results with the original protocol. The shorter N1 primers amplify the same area, may give more consistent results (data not shown) and may increase primer stability during freeze/thawing cycles but did not lead to improved sensitivity for the 240 samples tested in the current study.

Secondly, the current study presents evidence that increasing the amount of filter paper material for DNA extraction results in an increased sensitivity. Although this finding is intuitively correct, its actual relevance for determining parasite prevalence in field studies has not been described in detail before. One could argue that a single copy of template material may result in successful amplification and therefore only infections with densities close to the threshold density for detection by PCR would give discordant PCR results. The current findings suggest that this is frequently the case and that doubling filter paper material can lead to parasite prevalence estimates that are up to $3.8 \%$ higher.
Thirdly, the results illustrate the stochastic nature of PCR. Although the agreement between PCR outcomes was very high, agreement was never perfect. Discordant PCR results were common, especially if single filter paper punches were used. Importantly, some PCRs performed on single filter paper punches detected parasites while the same PCR on double filter paper punches did not. This serves as a word of warning against assuming $100 \%$ sensitivity of PCR. It has been previously acknowledged that PCR assays may fail to detect all circulating parasite clones $[50,51]$, the current study indicates that this imperfection of PCR assays may also affect parasite prevalence estimates. The exploratory experiments described in this study on the distribution of parasite material on filter papers may be relevant in this respect: the amount of parasite material can differ by more than $15 \%$ between different punches from the same bloodspot despite the blood completely wetting the paper.

\section{Conclusion}

When the combined DNA extraction-serum elution methodology is used, robust PCR and ELISA results can be obtained. The combined approach can significantly reduce the workload in large-scale epidemiological studies and allow efficient use of blood spot material for molecular and immunological assays. The efficient use of blood spot material may allow researchers to increase the amount of filter paper material that is used for this 
combined extraction. This will increase PCR sensitivity and may increase robustness of parasite prevalence estimates.

\section{Additional files}

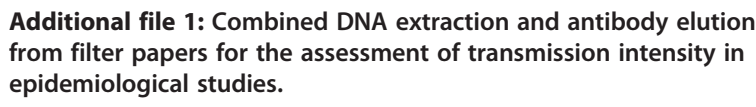

Additional file 2: Agreement between $18 \mathrm{~s}$, modified cytochrome b and original cytochrome b PCR assays when a single sample is considered a true positive when positive in at least two PCR assays.

\section{Competing interests}

The authors declared that they have no competing interests.

\section{Authors' contributions}

$A B$ and WS designed the experiments, carried out the molecular and immunoassays, and drafted the manuscript. $A B, J S, C D, T B$ designed the field studies and $A B, J S$ and $V O$ supervised sample collection. SS, VO and EM participated in the running of molecular and immunoassays. IP and $A B$ participated in the cell and antibody distribution experiments. LG, JS, SK, CS, CD and RS revised the manuscript. TB conceived the experiments, aided their design, and contributed to the drafting and revision of the manuscript. All authors read and approved the final manuscript.

\section{Acknowledgements}

We thank project staff, the community of Kabondo and Kasipul, Rachuonyo South, and KEMRI/CDC Kisumu. In addition we would like to thank Patrick Corran for his advice on the filter paper antibody distribution experiments. We would also like to thank Alanna Swartz and Bryan Greenhouse for the fruitful discussions on this subject. This project was funded by the Bill and Melinda Gates Foundation as part of a Grand Challenge project (Grant No. OPP1024438) and the Malaria Transmission Consortium (Grant No. 45114). This manuscript was submitted for publication with approval of the director of the Centre for Global Health Research, Kenyan Medical Research Institute, Kisumu.

\section{Author details}

${ }^{1}$ Department of Medical Microbiology, Radboud University Nijmegen Medical Centre, Nijmegen, the Netherlands. ${ }^{2}$ Centre for Global Health Research, Kenya Medical Research Institute and Centers of Disease control and prevention, Kisumu, Kenya. ${ }^{3}$ Department of Disease Control, Faculty of Infectious and Tropical Diseases, London School of Hygiene and Tropical Medicine, London WC1E 7HT, UK. ${ }^{4}$ Department of Immunology \& Infection, Faculty of Infectious and Tropical Diseases, London School of Hygiene and Tropical Medicine, London WC1E 7HT, UK.

Received: 17 February 2013 Accepted: 30 June 2013

Published: 2 August 2013

\section{References}

1. Oesterholt M, Bousema JT, Mwerinde OK, Harris C, Lushino P, Masokoto A, Mwerinde $\mathrm{H}$, Mosha FW, Drakeley CJ: Spatial and temporal variation in malaria transmission in a low endemicity area in northern Tanzania. Malar J 2006, 5:1-7.

2. Drakeley C, Schellenberg D, Kihonda J, Sousa CA, Arez AP, Lopes D, Lines J, Mshinda H, Lengeler C, Schellenberg JA, Tanner M, Alonso P: An estimation of the entomological inoculation rate for Ifakara: a semi-urban area in a region of intense malaria transmission in Tanzania. Trop Med Int Health 2003, 8:767-774.

3. Smith DL, Drakeley CJ, Chiyaka C, Hay SI: A quantitative analysis of transmission efficiency versus intensity for malaria. Nat Commun 2010, $1: 108$

4. Harris I, Sharrock W, Bain L, Gray K-A, Bobogare A, Boaz L, Lilley K, Krause D, Vallely A, Johnson M-L, Gatton ML, Shanks GD, Cheng Q: A large proportion of asymptomatic Plasmodium infections with low and submicroscopic parasite densities in the low transmission setting of Temotu
Province, Solomon Islands: challenges for malaria diagnostics in an elimination setting. Malar J 2010, 9:254

5. Satoguina J, Walther B, Drakeley C, Nwakanma D, Oriero E, Correa S, Corran $\mathrm{P}$, Conway D, Walther M: Comparison of surveillance methods applied to a situation of low malaria prevalence at rural sites in The Gambia and Guinea Bissau. Malar J 2009, 8:274.

6. Okell LC, Ghani AC, Lyons E, Drakeley CJ: Submicroscopic infection in Plasmodium falciparum-endemic populations: a systematic review and meta-analysis. J Infect Dis 2009, 200:1509-1517.

7. The malEra Consultative Group on Monitoring, Evaluation and, Surveillance: A Research agenda for malaria eradication: monitoring, evaluation, and surveillance. PLoS Med 2011, 8:e1000400.

8. Yekutiel P: Problems of epidemiology in malaria eradication. Bull World Health Organ 1960, 22:669-683.

9. Bhattarai A, Ali AS, Kachur SP, Mårtensson A, Abbas AK, Khatib R, Al-Mafazy AW, Ramsan M, Rotllant G, Gerstenmaier JF, Molteni F, Abdulla S, Montgomery SM, Kaneko A, Björkman A: Impact of artemisinin-based combination therapy and insecticide-treated nets on malaria burden in Zanzibar. PLoS Med 2007, 4:e309.

10. Okiro E, Hay S, Gikandi P, Sharif S, Noor A, Peshu N, Marsh K, Snow R: The decline in paediatric malaria admissions on the coast of Kenya. Malar J 2007, 6:151.

11. Mmbando BP, Vestergaard LS, Kitua AY, Lemnge MM, Theander TG, Lusingu JP: A progressive declining in the burden of malaria in north-eastern Tanzania. Malar J 2010, 9:216.

12. O'Meara WP, Mangeni JN, Steketee R, Greenwood B: Changes in the burden of malaria in sub-Saharan Africa. Lancet Infect Dis 2010, 10:545-555.

13. O'Meara WP, Bejon P, Mwangi TW, Okiro EA, Peshu N, Snow RW, Newton CRJC, Marsh K: Effect of a fall in malaria transmission on morbidity and mortality in Kilifi, Kenya. Lancet 2008, 372:1555-1562.

14. Barnes Kl, Durrheim DN, Little F, Jackson A, Mehta U, Allen E, Dlamini SS, Tsoka J, Bredenkamp B, Mthembu DJ, White NJ, Sharp BL: Effect of artemether-lumefantrine policy and improved vector control on malaria burden in KwaZulu-Natal, South Africa. PLoS Med 2005, 2:e330.

15. Alonso PL, Brown G, Arevalo-Herrera M, Binka F, Chitnis C, Collins F Doumbo OK, Greenwood B, Hall BF, Levine MM, Mendis K, Newman RD, Plowe CV, Rodríguez MH, Sinden R, Slutsker L, Tanner M: A research agenda to underpin malaria eradication. PLoS Med 2011, 8:e1000406.

16. Drakeley CJ, Corran PH, Coleman PG, Tongren JE, McDonald SLR, Carneiro I, Malima R, Lusingu J, Manjurano A, Nkya WMM, Lemnge MM, Cox J, Reyburn $\mathrm{H}$, Riley EM: Estimating medium- and long-term trends in malaria transmission by using serological markers of malaria exposure. Proc Natl Acad Sci USA 2005, 102:5108-5113.

17. Bousema T, Youssef RM, Cook J, Cox J, Alegana VA, Amran J, Noor AM, Snow RW, Drakeley C: Serologic markers for detecting malaria in areas of low endemicity, Somalia, 2008. Emerg Infect Dis 2010, 16:392-399.

18. Bousema T, Drakeley C, Gesase S, Hashim R, Magesa S, Mosha F, Otieno S, Carneiro I, Cox J, Msuya E, Kleinschmidt I, Maxwell C, Greenwood B, Riley E, Sauerwein R, Chandramohan D, Gosling R: Identification of hot spots of malaria transmission for targeted malaria control. J Infect Dis 2010, 201:1764-1774.

19. Cook J, Kleinschmidt I, Schwabe C, Nseng G, Bousema T, Corran PH, Riley EM, Drakeley CJ: Serological markers suggest heterogeneity of effectiveness of malaria control interventions on Bioko Island, Equatorial Guinea. PLoS One 2011, 6:e25137.

20. Stewart L, Gosling R, Griffin J, Gesase S, Campo J, Hashim R, Masika P, Mosha J, Bousema T, Shekalaghe S, Cook J, Corran P, Ghani A, Riley EM, Drakeley C: Rapid assessment of malaria transmission using age-specific sero-conversion rates. PLoS One 2009, 4:e6083.

21. Singh B, Bobogare A, Cox-Singh J, Snounou G, Abdullah M, Rahman H: A genus- and species-specific nested polymerase chain reaction malaria detection assay for epidemiologic studies. Am J Trop Med Hyg 1999, 60:687-692.

22. Snounou G, Pinheiro L, Goncalves A, Fonseca L, Dias F, Brown K, do Rosario $V$ : The importance of sensitive detection of malaria parasites in the human and insect hosts in epidemiological studies, as shown by the analysis of field samples from Guinea Bissau. Trans $R$ Soc Trop Med Hyg 1993, 87:649-653.

23. Snounou G, Viriyakosol S, Zhu X, Jarra W, Pinheiro L, Rosario V do, Thaithong S, Brown K: High sensitivity of detection of human malaria 
parasites by the use of nested polymerase chain reaction. Mol Biochem Parasitol 1993, 61:315-320.

24. Okell LC, Bousema T, Griffin JT, Ouedraogo AL, Ghani AC, Drakeley CJ: Factors determining the occurrence of submicroscopic malaria infections and their relevance for control. Nat Comm 2012, 3:1237

25. Ouedraogo AL, Bousema T, Schneider P, de Vlas SJ, Ilboudo-Sanogo E, Cuzin-Ouattara N, Nebie I, Roeffen W, Verhave JP, Luty AJ, Sauerwein R: Substantial contribution of submicroscopical Plasmodium falciparum gametocyte carriage to the infectious reservoir in an area of seasonal transmission. PLoS One 2009, 4:e8410.

26. Bousema T, Drakeley C: Epidemiology and infectivity of Plasmodium falciparum and Plasmodium vivax gametocytes in relation to malaria control and elimination. Clin Microbiol Rev 2011, 24:377-410.

27. Bousema T, Griffin JT, Sauerwein RW, Smith DL, Churcher TS, Takken W, Ghani A, Drakeley C, Gosling R: Hitting hotspots: spatial targeting of malaria for control and elimination. PLOS Med 2012, 9:e1001165.

28. Gosling RD, Okell L, Mosha J, Chandramohan D: The role of antimalarial treatment in the elimination of malaria. Clin Microbiol Infection 2011, 17:1617-1623.

29. Steenkeste N, Incardona S, Chy S, Duval L, Ekala M, Lim P, Hewitt S, Sochantha T, Socheat D, Rogier C, Mercereau-Puijalon O, Fandeur T, Ariey F: Towards high-throughput molecular detection of Plasmodium: new approaches and molecular markers. Malar J 2009, 8:86.

30. Hsiang MS, Lin M, Dokomajilar C, Kemere J, Pilcher CD, Dorsey G, Greenhouse B: PCR-based pooling of dried blood spots for detection of malaria parasites: optimization and application to a cohort of Ugandan children. J Clin Microbiol 2010, 48:3539-3543.

31. Hwang J, Jaroensuk J, Leimanis M, Russell B, McGready R, Day N, Snounou G, Nosten F, Imwong M: Long-term storage limits PCR-based analyses of malaria parasites in archival dried blood spots. Malar J 2012, 11:339.

32. Moonen B, Cohen JM, Snow RW, Slutsker L, Drakeley C, Smith DL, Abeyasinghe RR, Rodriguez MH, Maharaj R, Tanner M, Targett G: Operational strategies to achieve and maintain malaria elimination. Lancet 2010, 376:1592-1603.

33. Bousema T, Stevenson J, Baidjoe A, Stresman G, Griffin J, Kleinschmidt I, Remarque E, Vulule J, Bayoh N, Laserson K, Desai M, Sauerwein R, Drakeley C, Cox J: The impact of hotspot-targeted interventions on malaria transmission: study protocol for a cluster-randomized controlled trial. Trials 2013, 14:36.

34. Corran PH, Cook J, Lynch C, Leendertse H, Manjurano A, Griffin J, Cox J, Abeku T, Bousema T, Ghani AC, Drakeley C, Riley E: Dried blood spots as a source of anti-malarial antibodies for epidemiological studies. Malar J 2008, 7:195.

35. Proietti C, Pettinato DD, Kanoi BN, Ntege E, Crisanti A, Riley EM, Egwang TG, Drakeley $\mathrm{C}$, Bousema $\mathrm{T}$ : Continuing intense malaria transmission in Northern Uganda. Am J Trop Med Hyg 2011, 84:830-837.

36. Steenkeste N, Rogers WO, Okell L, Jeanne I, Incardona S, Duval L, Chy S, Hewitt S, Chou M, Socheat D, Babin FX, Ariey F, Rogier C: Sub-microscopic malaria cases and mixed malaria infection in a remote area of high malaria endemicity in Rattanakiri province, Cambodia: implication for malaria elimination. Malar J 2010, 9:108.

37. Franke-Fayard B, Waters AP, Janse $C J$ : Real-time in vivo imaging of transgenic bioluminescent blood stages of rodent malaria parasites in mice. Nat Protoc 2006, 1:476-485.

38. Janse CJ, Franke-Fayard B, Waters AP: Selection by flow-sorting of genetically transformed, GFP-expressing blood stages of the rodent malaria parasite, Plasmodium berghei. Nat Protoc 2006, 1:614-623.

39. Franke-Fayard B, Djokovic D, Dooren MW, Ramesar J, Waters AP, Falade MO, Kranendonk M, Martinelli A, Cravo P, Janse CJ: Simple and sensitive antimalarial drug screening in vitro and in vivo using transgenic luciferase expressing Plasmodium berghei parasites. Int J Parasitol 2008, 38:1651-1662

40. Drakeley C, Cook J: Potential contribution of sero-epidemiological analysis for monitoring malaria control and elimination: historical and current perspectives. Adv Parasitol 2009, 69:299-352.

41. Rizzo C, Ronca R, Fiorentino G, Mangano V, Sirima S, Nebie I, Petrarca V, Modiano D, Arca B: Wide cross-reactivity between Anopheles gambiae and Anopheles funestus SG6 salivary proteins supports exploitation of gSG6 as a marker of human exposure to major malaria vectors in tropical Africa. Malar J 2011, 10:206.
42. Rizzo C, Ronca R, Fiorentino G, Verra F, Mangano V, Poinsignon A, Sirima SB, Nèbiè I, Lombardo F, Remoue F, Coluzzi M, Petrarca V, Modiano D, Arcà B: Humoral response to the Anopheles gambiae salivary protein gSG6: a serological indicator of exposure to Afrotropical malaria vectors. PLOS One 2011, 6:e17980.

43. Stone W, Bousema T, Jones S, Gesase S, Hashim R, Gosling R, Carneiro I, Chandramohan D, Theander T, Ronca R, Modiano D, Arcà B, Drakeley C: IgG responses to Anopheles gambiae salivary antigen gSG6 detect variation in exposure to malaria vectors and disease risk. PLoS One 2012, 7:e40170.

44. Feachem RGA, Phillips AA, Targett GA (Eds): Shrinking the malaria map: a prospectus on malaria elimination. San Francisco: The Global Health Group, Global Health Sciences, University of California, San Francisco; 2009.

45. Cook J, Reid H, lavro J, Kuwahata M, Taleo G, Clements A, McCarthy J, Vallely A, Drakeley C: Using serological measures to monitor changes in malaria transmission in Vanuatu. Malar J 2010, 9:169.

46. Corran P, Coleman P, Riley E, Drakeley C: Serology: a robust indicator of malaria transmission intensity? Trends Parasitol 2007, 23:575-582.

47. Phillips K, McCallum N, Welch L: A comparison of methods for forensic DNA extraction: Chelex-100 ${ }^{\oplus}$ and the QIAGEN DNA Investigator Kit (manual and automated). Forensic Sci Int Genet 2012, 6:282-285.

48. Hsiang MS, Hwang J, Kunene S, Drakeley C, Kandula D, Novotny J, Parizo J, Jensen T, Tong M, Kemere J, Dlamini S, Moonen B, Angov E, Dutta S, Ockenhouse C, Dorsey G, Greenhouse B: Surveillance formalaria elimination in Swaziland: A national cross-sectional study using pooled PCR and serology. PLoS One 2012, 7:e29550.

49. Haanshuus CG, Mohn SC, Morch K, Langeland N, Blomberg B, Hanevik K: A novel, single-amplification PCR targeting mitochondrial genome highly sensitive and specific in diagnosing malaria among returned travellers in Bergen, Norway. Malar J 2013, 12:26.

50. Bretscher M, Valsangiacomo F, Owusu-Agyei S, Penny M, Felger I, Smith T: Detectability of Plasmodium falciparum clones. Malar J 2010, 9:234

51. Koepfli C, Schoepflin S, Bretscher M, Lin E, Kiniboro B, Zimmerman PA, Siba P, Smith TA, Mueller I, Felger I: How much remains undetected? probability of molecular detection of human Plasmodia in the field. PLoS One 2011, 6:e19010

doi:10.1186/1475-2875-12-272

Cite this article as: Baidjoe et al.: Combined DNA extraction and antibody elution from filter papers for the assessment of malaria transmission intensity in epidemiological studies. Malaria Journal $201312: 272$.

\section{Submit your next manuscript to BioMed Central and take full advantage of:}

- Convenient online submission

- Thorough peer review

- No space constraints or color figure charges

- Immediate publication on acceptance

- Inclusion in PubMed, CAS, Scopus and Google Scholar

- Research which is freely available for redistribution

Submit your manuscript at www.biomedcentral.com/submit
C) BioMed Central 